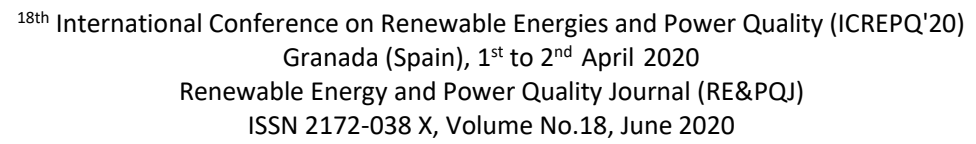

\title{
Electrification of the boat fleet of the Albufera Natural Park of Valencia: methodology, economic and environmental assessments
}

\author{
D. S. Bejarano-Cáceres ${ }^{1}$, D. Ribó-Pérez ${ }^{1}$ and M. Alcázar-Ortega ${ }^{1}$ \\ ${ }^{1}$ Department of Electrical Engineering \\ E.T.S.I.I., Universitat Politècnica de Valencia \\ Cami de Vera s/n, 46022 Valencia (Spain) \\ Phone/Fax number: (+34) 963879244 (ext. 88917), e-mail: david.ribo@iie.upv.es
}

\begin{abstract}
Summary. This article presents a methodology for calculating the energy needs to propose the electrification of a fleet of small boats. A technical, economic and environmental analysis of the transition to electric mobility of the fleet of boats in the wetland of the Albufera Natural Park of Valencia (Spain) is presented and analysed. The environmental benefits of this transition are explored and an economic assessment is done, including the evaluation of the necessary public incentives to capture all the benefits related to this transition and make it feasible.
\end{abstract}

Key words. Electric boats, energy transition, wetlands, Albufera.

\section{Introduction}

The ecosystem of the Albufera Natural Park, located a few kilometres from the city of Valencia (Spain) represents a valuable habitat for a wide variety of fauna and flora. It also acts as a sink for greenhouse gases through the photosynthetic assimilation of carbon dioxide $\left(\mathrm{CO}_{2}\right)$ from the atmosphere [1]. Throughout the 1980s and 1990s, it was recognized as a "Wetland of International Importance" and "Special bird protection zone (ZEPA)" [2] in addition to becoming part of the Natura 2000 Network. The importance of the ecosystem mainly lies in the 350 species of birds that annually use the ecosystem [3]. Nevertheless, anthropogenic activities are jeopardising this ecosystem, which is stated to be in a critical situation.

One of the lake activities is related to the utilization of aquatic vehicles. Many boats carry out fishing activities, tourist trips and maintenance work, which have significant impacts on the park's ecosystem. They discharge unburned fuel into the lake water, polluting gases into the atmosphere and generate high noise levels produced by combustion engines.

For years, the lake has been suffering from eutrophication problems due to nutrient excesses because of inadequately treated wastewater discharges. Simultaneously, it has been receiving less fresh water from its main supplier (the Júcar River), reducing the water renewals of the lake and affecting its quality. Measures need to be taken in order to improve the current state of the ecosystem of the Albufera Natural Park, which is in a critical state [4].
One of these measures is the electrification of the boats that circulate on the lake. This article presents a methodology for calculating the energy needs of boats to propose an electric boat design. Therefore, a technical, economic and environmental analysis of the transition to electric motors of the fleet of boats in the Albufera is presented and analysed.

\section{Methodology}

Figure 1 presents the developed methodology, represented as a block diagram. First, the parameters to study are chosen to identify the data that should be collected. In this case, the aim is to determine the energy demand of the propulsion system to ensure the movement of the vessel. To do so, data must be collected on diesel consumption, circulation speed and work activity schedule, among others.

To ensure a correct sizing and calculation of the elements of the boat, the energy needs are estimated in two different ways. Firstly, throughout an energy balance. Then, setting out a balance of forces. Afterwards, the consistency of the results obtained is evaluated. If results from both methodologies do not match, the selection of variables, the data collection and the calculation process is carried out again.

Once the energy needs are validated, the charging process and the components of the electric propulsion system (electric motor, batteries, etc.) are sized. Once the components have been sized, the solution is proposed, and the investment costs are estimated. On the other hand, the environmental benefits of the electrification are analysed (noise, emissions of polluting gases, discharges, etc.).

Finally, the obtained design and results need to be discussed with the fishing community, boat workers and ship captains to get their agreement. If the proposal is not approved, the loading process and components should be resized with the users' inputs until the proposal is accepted. Then, the approved prototype may be designed. 


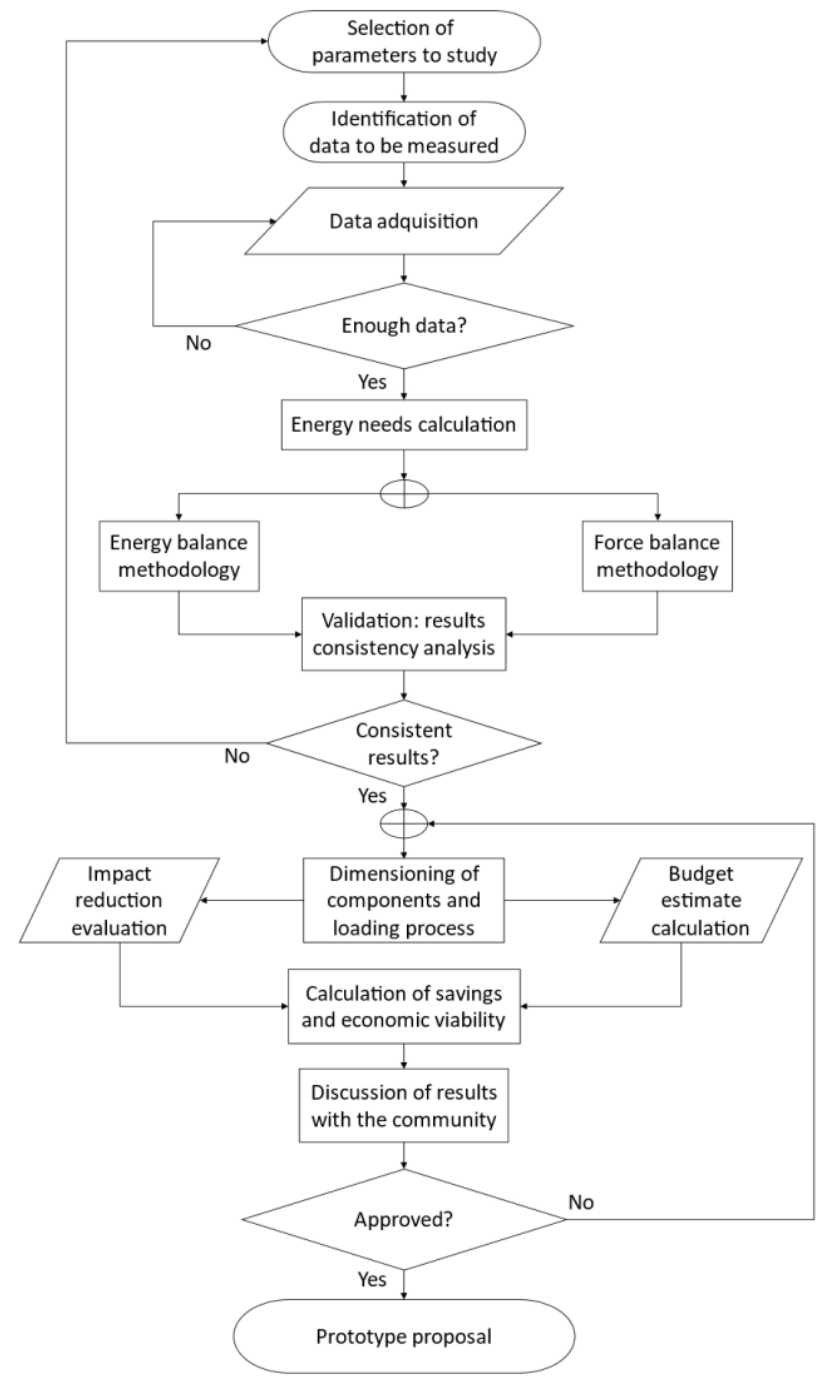

Figure 1. Diagram of blocks of the methodology.

\section{A. Energy balance methodology}

In order to find the power of the motors and the energy capacity of the batteries, the following energy balance is considered. By means of equation (1) the useful energy of the combustion process for the boat motion is calculated.

$$
E_{\text {useful }}=l \cdot \rho \cdot P C I \cdot \eta_{M T} \cdot \eta_{P R O P}
$$

Where:

- $\quad l$ : volume of diesel consumed on a trip, in litres.

- $\quad \rho$ : density of diesel. $0.82 \mathrm{~kg} / \mathrm{l}\left(\right.$ at $15^{\circ} \mathrm{C}$ ) is considered [5].

- $\quad L H V$ : lower heating value of diesel. $11.8 \mathrm{kWh} / \mathrm{kg}$ is considered [6].

- $\quad \eta_{M T}$ : diesel engine efficiency.

- $\quad \eta_{P R O P}$ : propulsion system efficiency.

- $\quad E_{\text {useful }}$ : useful combustion energy destined to the movement of the boat $(\mathrm{kWh})$.

Equation (2) presents the chemical energy stored in the batteries and its conversion efficiency into electricity.

$$
E_{\text {useful }}=C_{B A T} \cdot \eta_{M E} \cdot \eta_{\text {CONTR }} \cdot \eta_{B A T} \cdot \eta_{P R O P}
$$

Where:
- $\quad C_{B A T}$ : battery capacity $(\mathrm{kWh})$

- $\quad \eta_{M E}$ : electric motor efficiency. A constant efficiency of $90 \%$ is assumed [7].

- $\quad \eta_{\text {CONTR: }}$ electronic controller efficiency. A constant efficiency of $95 \%$ is assumed [8]

- $\quad \eta_{B A T}$ : performance of lithium batteries. It assumes a constant yield of $90 \%$ [9].

$\eta_{P R O P}$ : propulsion system performance. It is assumed a value identical to that of current boats as only the engine will be changed from the propulsion system.

With both equations, the capacity that the batteries should supply is obtained. Then, the average power $\left(P_{M E D}\right)$ for the electric motor is calculated considering the duration of the boat trip $(t)$ and the electrical energy demanded during the trip (battery capacity), obtained by the following expression:

$$
P_{M E D}=\frac{C_{B A T}}{t}
$$

\section{B. Force balance methodology}

An alternative way for calculating the useful energy from the point of view of the forces that the vessel must overcome in order to advance is considered. First, the forces involved in the balance are defined. On one hand, there is the motive force $\left(F_{\text {motor }}\right)$, which is carried out by the propulsion system that moves the boat; and, on the other hand, the drag forces of the boat due to contact with water $\left(F_{D \text { water }}\right)$ and air $\left(F_{D \text { wind }}\right)$. The result of the balance causes the movement of the boat $(m \cdot \vec{a})$. Thus, the balance of forces is defined as the following expression:

$$
F_{\text {motor }}-F_{D \text { water }}-F_{D \text { wind }}=m \cdot \vec{a}
$$

The drag force of the water is that necessary to overcome the resistance that it opposes in the direction of the flow of the boat's advance due to the combined effects of friction and pressure forces. This force is defined as follows:

$$
F_{D \text { water }}(t)=\frac{1}{2} \cdot \rho \cdot C_{D}(t) \cdot A \cdot V(t)^{2}
$$

Where:

- $\rho$ : water density. A density of $1000 \mathrm{~kg} / \mathrm{m}^{3}$, freshwater value, is assumed.

- $\quad V(t)$ : boat speed $(\mathrm{m} / \mathrm{s})$. The speed of the water is not taken into account, as it is a lake and the water remains still.

- $A$ : wet area. It represents the surface of the boat submerged under the water $\left(\mathrm{m}^{2}\right)$.

- $C_{D}(t)$ : coefficient of resistance to the boat's advance when in contact with water. It is the sum of the coefficients of friction and pressure.

To simplify, in the calculation of $C_{D}$, it is considered that the bottom of the boat is a smooth flat plate. This coefficient depends on the Reynolds number $(R e)$.

On the other hand, in the case of a parallel flow on a smooth flat plate, the drag due to pressure is null, so the total drag coefficient is equal to the friction coefficient $\left(C_{f}\right)$ [10]. Thus, the drag coefficient is calculated as follows [11]: 


$$
C_{f}(t)=\frac{0,074}{R e_{L}(t)^{\frac{1}{5}}}-\frac{1740}{R e_{L}(t)} \quad 5 \cdot 10^{5} \lesssim R e_{L} \lesssim 10^{7}
$$

The calculation of $R e$ is performed for the end boat by the following expression:

$$
\operatorname{Re}_{L}(t)=\frac{V(t) \cdot L}{v}
$$

Where:

$$
\begin{aligned}
& \text { - } \quad L \text { : boat length }(\mathrm{m}) \text {. } \\
& \text { - } \quad v \text { : kinematic viscosity of water. A value of } \\
& 1,036 \cdot 10^{-6} \mathrm{~m}^{2} / \mathrm{s} \text { is assumed. } \\
& \text { - } \quad V(t): \text { boat speed }(\mathrm{m} / \mathrm{s}) \text {. }
\end{aligned}
$$

At low speed, almost all the drag force of the water corresponds to the friction [12]. However, for boats circulating at low speed, the friction force is estimated as $85 \%$ of the total force [13]. Thus, the total drag force of the water is:

$$
F_{T \text { water }}(t)=\frac{F_{D \text { water }}(t)}{0,85}
$$

On the other hand, the drag force of the air represents the force necessary to overcome the resistance of the air (wind) to the advance of the boat. It is calculated by the following expression:

$$
F_{D \text { wind }}(t)=\frac{1}{2} \cdot \rho \cdot C_{D} \cdot A \cdot\left(V(t)+V_{\text {wind }}\right)^{2}
$$

Where:

- $\quad \rho$ : air density. A value of $1.22 \mathrm{~kg} / \mathrm{m}^{3}$ is assumed.

- $\quad V(t)$ : boat speed $(\mathrm{m} / \mathrm{s})$.

- $\quad V_{\text {wind }}$ : wind speed $(\mathrm{m} / \mathrm{s})$.

- $\quad C_{D}$ : aerodynamic drag coefficient of the boat.

- $A$ : projection of the front area of the boat $\left(\mathrm{m}^{2}\right)$.

The third term in the balance is the force resulting from the motive and drag forces, which represents the movement and inertial force of the vessel. It is calculated by the following expression:

$$
F(t)=m \cdot a(t)
$$

Where:

$m$ : total mass of the vessel. It is the sum of the mass of the passengers on board (an average weight of $80 \mathrm{~kg}$ per person is considered) and the weight of the boat (about $1250 \mathrm{~kg}$ ).

- $\quad \vec{a}(t)$ : acceleration of the boat. It is calculated as follows:

$$
\vec{a}(t)=\frac{\Delta V}{\Delta t}=\frac{V(t)-V(t-1)}{1}
$$

Finally, the motor force is calculated as a function of the remaining forces, clearing it from equation (3). In this way, the following expression results:

$$
F_{\text {motor }}(t)=F_{\text {Twater }}(t)+F_{D \text { wind }}(t)+m \cdot a(t)
$$

\section{Corrections in the calculation process}

During the resolution of the force balance, negative values of $F_{\text {motor }}$ have been obtained in some instants of each path due to the moments in which the speed decreases. The negative value means that the propulsion system has the capacity to store energy, and this is not possible as no energy storage mechanism is available.

Therefore, when speed is reduced $(\mathrm{a}<0)$, the motor force to be provided by the propulsion system is only the necessary to overcome the drag forces of water and wind. Thus, for these moments, the balance of forces to be resolved is as follows:

$$
\begin{aligned}
& F_{\text {motor }}= \\
& \left\{\begin{array}{c}
F_{\text {Twater }}(t)+F_{D \text { wind }}(t)+m \cdot a(t), \text { if } a>0 \\
F_{D \text { water }}+F_{D \text { wind }}, \quad \text { if } a<0
\end{array}\right\}
\end{aligned}
$$

On the other hand, some "noise" has been detected in the speed data recorded on-site during the data measurement [14]. To overcome this measurement error, a speed filter to smooth out the fluctuations is applied [15]:

$$
V^{\prime}(t)=\frac{V_{t+2}+V_{t+1}+V_{t}+V_{t-1}+V_{t-2}}{5}
$$

Thus, from now, when writing $V(t)$ it will be understood the corrected velocity $V^{\prime}(t)$ for subsequent equations.

\section{Force balance resolution}

The driving power required to move the boat could be expressed as follows:

$$
P_{\text {useful }}(t)=F_{\text {motor }}(t) \cdot V(t)
$$

If the boat is propelled by an electric motor, the electrical power required can be calculated by the following expression:

$$
P(t)=\frac{P_{u s e f u l}(t)}{\eta_{M E} \cdot \eta_{P O T} \cdot \eta_{B A T} \cdot \eta_{P R O P}}
$$

In this way, in addition to the speed curve, an electric power curve is obtained and thus, the working power range of the electric motor. The total electricity demanded in the boat ride will be equal to the area enclosed by the electric power curve. The batteries must have enough capacity to store and give the electrical energy demanded. Therefore, in order to calculate it, the trapeze method [16] is applied, which in this case consists of adding the semi sum of the powers of the instant and the previous instant.

Additionally, the thermal efficiency of the diesel engine can be calculated from the balance of forces. To do this, equations (1) and (2) are equated and the performance of the diesel engine is cleared, depending on the capacity of the batteries and the diesel consumed, among others. Thus, the performance of the thermal engine is calculated as follows:

$$
\eta_{M T}=\frac{C_{B A T} \cdot \eta_{M E} \cdot \eta_{B A T} \cdot \eta_{C O N T R}}{l \cdot \rho \cdot P C I}
$$

Being all the variables previously defined. 


\section{Case study}

The study has been applied to the boats fleet used for touristic promenades at the district of El Palmar.

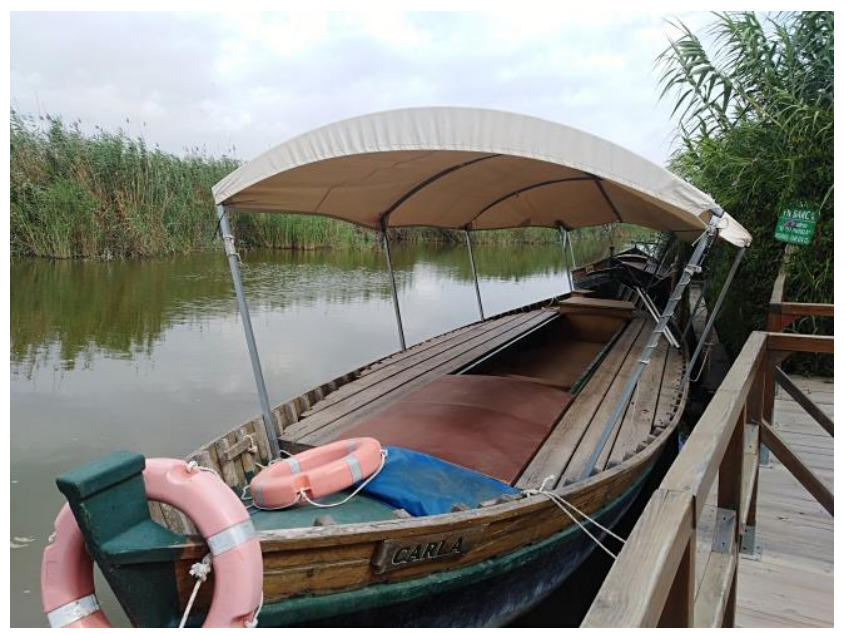

Figure 2. 2Touristic tour boat at El Palmar.

\section{A) Data acquisition}

The aim of this phase is to obtain information on working activity and energy needs.

Regarding the working activity, the workers themselves have been surveyed on the number of touristic boat trips carried out during the year and in high season, as well as working hours in winter and summer to plan the availability of loading hours.

In order to collect data on energy needs, field work has been performed on board of the boats, during which such parameters as the speed and geographical coordinates of the boat have been measured at every second, using the aforementioned application [14]. In addition, the litres of diesel consumed in each trip were measured, observing the variation in the boat's tank. The number of passengers on board were also written down on each trip, as well as the wind speed recorded at the nearest weather station [17].

The following table shows average data for registered trips:

Table 1. Average data of registered travel.

\begin{tabular}{lc}
\hline Average speed $(\mathrm{km} / \mathrm{h})$ & 6.99 \\
Distance traveled $(\mathrm{km})$ & 4.13 \\
Diesel consumed on each trip (1) & 0.76 \\
Number of regular daily trips & $3-5$ \\
Number of travel days in high season & $6-8$ \\
\hline
\end{tabular}

\section{B) Resolution}

In the resolution of the energy balance an efficiency of the current engines, $\eta_{M T}$, of $25 \%$ has been considered. Typical value of small diesel engines [18] and a propulsion system efficiency of $50 \%$, typical of inboard axle systems [12], have been also taken into account.

Considering the average diesel consumption per trip from Table 1, equations (1) and (2) are equated and the capacity of the batteries is cleared. Thus, it is estimated that 2.37 $\mathrm{kWh}$ are needed on each trip. The time for boat trip ranges between 35-40 minutes and the average power that the electric motor should provide is approximately $4 \mathrm{~kW}$. Therefore, so as to dimension the batteries for the average annual work, in which 3 to 5 trips are made, capacity sizes of $11.87 \mathrm{kWh}$ (for 5 trips) would be needed per storage device.

On the other hand, the following figure shows some useful dimensions of the boat for the resolution of the balance of forces. The length $(12 \mathrm{~m})$ corresponds to the maximum possible according to the local regulation [19].
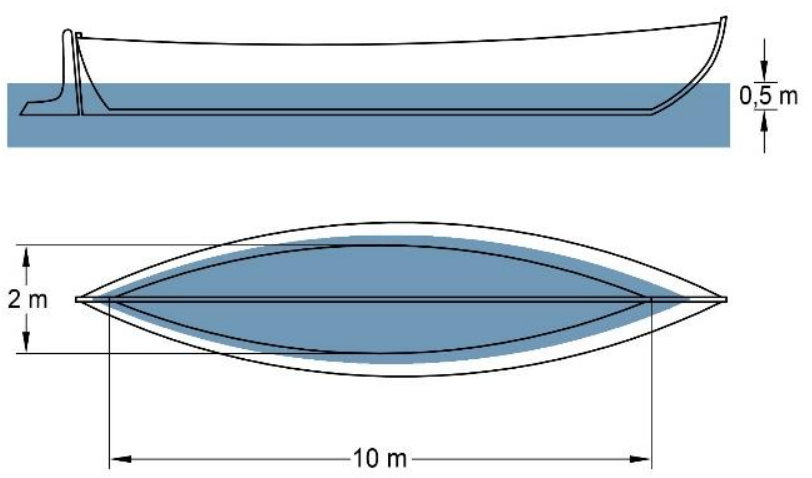

Figure 3. Dimensions of the boat.

For the calculation of the drag force of the water, the area of the wetted surface has been approximated to the surface of the side walls plus the area of the bottom of the boat. The area of the lower part is obtained from the boat dimensions, which gives an area of $13.44 \mathrm{~m}^{2}$. The area of the side walls approximates that of trapeziums multiplied by a curvature factor of 1.8. It is assessed that the total wetted surface is $32.34 \mathrm{~m}^{2}$.

For the calculation of the air drag force, it is considered that the beam and freeboard of the vessel are $2.85 \mathrm{~m}$ and $0.6 \mathrm{~m}$ respectively, and that the front area occupied by passengers on each side of the vessel is about $0.3 \mathrm{~m}^{2}$. Thus, a total frontal area of $2.27 \mathrm{~m}^{2}$ is evaluated. On the other hand, an aerodynamic drag coefficient value of 0.7 is estimated, that is considered in different sources as a typical value for sailboats [20], oil tankers [21] and tunnel boats [22].

Considering the data collected from the case study, and following the calculation methodology, the following results are obtained per touristic boat trip:

Table 2. Summary Table of Results.

\begin{tabular}{cc}
\hline$C_{B A T}(k W h)$ & 0.81 \\
$P_{M E D}\left(k W_{e}\right)$ & 1.38 \\
$P_{M A X}\left(k W_{e}\right)$ & 5.21 \\
$\eta_{M T}(\%)$ & 8.91 \\
\hline
\end{tabular}

\section{C) Economic viability}

Among the different options for sizing the charging process and batteries, it has been considered that the option that best suits the case study is the sizing of the batteries for the worst-case scenario (high season 6-8 trips) and the possibility that the batteries can be removed. These options have advantages such as not having deep discharges during most of the year, which negatively affects the useful life of the batteries [23]. Furthermore, they can be charged in the 
workers' own homes and, therefore, it reduces the risk of theft.

The batteries are dimensioned for 8 trips, plus a security coefficient of $20 \%$. The ion-lithium technology is chosen because they present greater comfort in transport (less weight) and they are becoming the major technology under the new mobility paradigm [9]. Batteries with a capacity of $7.81 \mathrm{kWh}$ and electric motors power for ranges of $1-5 \mathrm{~kW}$ are considered necessary. On the other hand, to make the transport of the batteries more comfortable, the option of having a pair of small batteries instead of a large one is preferred.

In this way, checking the equipment prices with different suppliers, the following costs and component characteristics are estimated:

Table 3. 3Summary table of prices.

\begin{tabular}{ccc}
\hline Component & Characteristics & Price $(€)$ \\
\hline Engine + & $1-5 \mathrm{~kW}$ at $48 \mathrm{~V}$ & 5,000 \\
Controller & $3.9 \mathrm{kWh}, 48 \mathrm{~V}$ & $1,825 \times 2(2 \mathrm{uds})$ \\
Battery & $16 \mathrm{~kg}$ & $336 \times 2(2 \mathrm{uds})$ \\
Charger & $0.65 \mathrm{~kW}$ & 2,000 \\
Manpower & & 11,322 \\
Total & VAT included & \\
\hline
\end{tabular}

It is considered that, even though in high season between 68 trips are made by boat, the annual average of daily trips varies from 3 to 5 trips. Estimating that, on average, 4 trips per day are made annually, 310 working days, and knowing the demand for electricity and diesel consumption per trip, it is estimated an annual fuel saving of $707 €$ per boat.

The following table shows the results of the economic analysis:

Table 4. Summary table of the economic analysis.

\begin{tabular}{ll}
\hline \multicolumn{2}{c}{ Economic indicators } \\
\hline NPV (2\% interest rate) & $-9888.57 €$ \\
NPV (10\% interest rate) & $-13110.70 €$ \\
IRR & $-11.50 \%$ \\
15-year cash flow & $-5760.57 €$ \\
\hline
\end{tabular}

Taking also into account the savings in maintenance (40 $€ /$ year) and operation when ceasing to use a thermal engine (every 10-15 years the diesel engine is changed, resulting in a total cost of $1,700 €$ of the change), various economic indicators are calculated (NPV, IRR, cash flow) with a horizon of 15 years to assess economic viability. On the other hand, the useful life of the batteries has been taken in 1500 cycles of charge and discharge, from which the capacity of the batteries is considerably reduced, so it is expected that they will be replaced every 5 years. Therefore, the NPV and IRR reveal that the proposal is not economically profitable, while the cash flow shows that an economic incentive ( $51 \%$ of the initial investment) would be necessary to make it economically profitable. If the amortization costs of the diesel engines were not considered and if only fuel savings were considered, an incentive of $79 \%$ of the initial investment would be necessary.

\section{D) Reducing impacts}

On the other hand, the transition to electric motors of the boats is related to the reduction of environmental impacts that would help to recover the natural ecosystem of the Albufera Natural Park.

In first place, there would no longer be discharges of unburned hydrocarbons from the combustion process, which would improve the quality of the lake water, which at present is in a critical situation [24].

Secondly, emissions of polluting gases that contribute to global warming would be reduced. Specifically, knowing the consumption of diesel and electrical energy and their respective emission coefficients, the carbon footprint would be reduced in $2 \mathrm{tCO}_{2} /$ year per boat, producing an overall reduction in El Palmar of $60 \mathrm{tCO}_{2}$ per year, since El Palmar has around 30 tourist boats.

Thirdly, one of the greatest benefits lies in the reduction of noise pollution from current diesel engines, which would be practically eliminated with electric motors. This reduction would improve the habitat conditions of the fauna of the Natural Park, as well as the working conditions of boatmen.

During the field study, the decibels emitted by the engine at different distances $(0.5$ and $8 \mathrm{~m})$ and in different states (during start-up and at idle) were measured with a sound level meter. The values recorded revealed that during the start and at $0.5 \mathrm{~m}$ (distance at which the boatmen are located when guiding the boat) more than $92 \mathrm{~dB}(\mathrm{~A})$ are emitted, which are reduced only to $78 \mathrm{~dB}(\mathrm{~A})$ when the distance increases up to 8 meters. These values far exceed the healthy limits [25], as well as the maximum thresholds set by local regulations [26]. In this sense, employees and boat captains reported problems with hearing loss related to this noise.

Finally, it should be noted that, given the international importance of the natural ecosystem of the Albufera (declared as "Wetland of international importance" and "Area of special protection for birds", among others), noise reduction would especially help to improve the habitat conditions of fauna. Indeed, 350 species of birds live in the Albufera (from which between 240 and 250 species are habitual residents) and even around 90 species reproduce every year in this Natural Park.

\section{Discussion and conclusions}

The electrification of boats would provide significant benefits in the natural ecosystem of the lake, and an early adaptation of the vehicles in la la Albufera. The unburned diesel combustion process would be stopped, the emissions of polluting gases that contribute to global warming would be reduced and noise pollution from the engine would be reduced. The latter is one of the greatest benefits due to the ecological importance of the Albufera ecosystem, as it is 
home to a great diversity of fauna and would help to improve habitat conditions. In addition, it would also lead to improvements in the working conditions of employees and boatmen, who are daily exposed to unhealthy noise levels.

On the other hand, we have estimated the economic support needed for the electrification. This would add to approximately $50 \%$ of the initial investment. This would make profitable this proposal in the short term and under the current conditions. However, keeping in mind the critical state of the Albufera ecosystem, the electrification of vessels should be considered as an interesting measure to improve the conditions of the lake, even though public incentives are necessary.

On the other hand, although the main components of the propulsion system and the loading process have been dimensioned, aspects of the design of the boat remain under discussion with the Fishermen's Community at El Palmar. Aspects such as the location of the batteries, the distribution of the components, and other actions to ensure that the final design is optimal for the work activity to be carried out will be future developments that are now on the table. Future research will focus on validating the studies carried out and deploying the obtained results in field pilots.

\section{Acknowledgements}

This work was supported in part by the Spanish public administration under the grant FPU2016/00962 and by the Cátedra de Transición Energética Urbana (Las NavesUPV).

\section{References}

[1] H. Brix, B. K. Sorrell, and B. Lorenzen, “Are phragmites-dominated wetlands a net source or net sink of greenhouse gases?," Aquat. Bot., vol. 69, no. 2-4, pp. 313-324, 2001.

[2] Servicio Devesa-Albufera. Ayuntamiento de Valencia, "L'albufera de València. Guía aves." 2019.

[3] Generalitat Valenciana, "L'albufera. Fauna," 2019. [Online]. Available: http://www.parquesnaturales.gva.es/es/web/pn-lalbufera/fauna-3817. [Accessed: 11-Mar-2019].

[4] C. Doña, V. Caselles, J. M. Sánchez, A. Ferri1, and A. Camacho, "Herramienta para el estudio del estado de Eutrofización de masas de agua continentales."

[5] BOE, "Real Decreto 61/2006, de 31 de enero, por el que se determinan las especificaciones de gasolinas, gasóleos, fuelóleos y gases licuados del petróleo y se regula el uso de determinados biocarburantes.," 2006.

[6] IDAE, "Estudios, informes y estadísticas," 2019. [Online]. Available: https://www.idae.es/estudiosinformes-y-estadisticas. [Accessed: 02-Oct-2019].
[7] R. B. Perpina and H. Martin, "El vehículo eléctrico y la eficiencia global. Vibro-Acoustics Design Optimization of the PMSMs View project," 2015.

[8] Á. I. Rodríguez Cea, "Modelo para la batería de ión de litio de un vehículo eléctrico," 2017.

[9] C. Peña Ordóñez, "Estudio de baterías para vehículos eléctricos.," 2011

[10] Y. A. Çengel, J. M. Cimbala, and J. E. Murrieta, Mecánica de fluidos : fundamentos y aplicaciones. 2007.

[11] E. Industrials and J. M. Bergad, "Mecánica de fluidos. Problemas resueltos," 2006.

[12] H. Ahadme Yahyai, "Estudio y diseño de una embarcación de 18,5 metros de eslora," 2017.

[13] J. M. de Juan-García Aguado, Principios de teoría del buque : dinámica. 1993.

[14] MATLAB, "Sensor Data Collection with MATLAB Mobile." [Online]. Available:

https://www.mathworks.com/help/matlabmobile/ug/sen sor-data-collection-with-matlab-mobile.html.

[Accessed: 12-Oct-2019].

[15] MathWorks, "Suavizado de señal." [Online]. Available: https://es.mathworks.com/help/signal/examples/signalsmoothing.html. [Accessed: 12-Oct-2019].

[16] Krantz, Steven George, and Krantz, Calculus demystified. McGraw-Hill, 2003.

[17] Avamet. Associació valenciana de meteorología Josep Peinado., "València l'Albufera/Tancat de la Pipa." [Online]. Available: https://www.avamet.org/mxrecords.php?id=c15m250e16. [Accessed: 12-Oct-2019].

[18] J. L. Ferreiro Castiñeira, "Estudio de eficiencia de un motor principal.," 2016

[19] Ayuntamiento de Valencia, "Ordenanza Reguladora del Registro de Embarcaciones del Lago de L'Albufera," 2019.

[20] A. Jansen, B. van Deursen, and C. Howe, "The aerodynamics of sailing apparel," Procedia Eng., vol 34, pp. 50-55, Jan. 2012.

[21] E. M. Lewandowski, The dynamics of marine craft : maneuvering and seakeeping. World Scientific, 2004.

[22] T. H. Reif and D. A. Guenther, "A Comparative Study of the Aerodynamics and Hydrodynamics of a Tunnel Boat Hull,” J. Hydronautics, vol. 12, no. 4, pp. 166168, Oct. 1978.

[23] O. P. Bairon, "Análisis del ciclo de vida de las baterías convencionales."

[24] Levante-EMV, "Medio ambiente en Valencia: 'El lago de la Albufera está en la UCI."” [Online]. Available: https://www.levante-emv.com/comunitatvalenciana/2019/10/04/lago-lalbuferauci/1929101.html. [Accessed: 21-Oct-2019].

[25] J. R. Chávez Miranda, "Ruido laboral," Cienc. y Trab., vol. 8,2006

[26] BOE, "Ley $7 / 2002$, de 3 de diciembre, de protección contra la contaminación acústica." [Online]. Available: https://www.boe.es/buscar/doc.php?id=BOE-A-2003613. [Accessed: 26-Oct-2019]. 